\title{
First record of acerola weevil, Anthonomus tomentosus (Faust, 1894) (Coleoptera: Curculionidae), in Brazil
}

\author{
A. L. Marsaro Júniora*, P. R. V. S. Pereira ${ }^{a}$, G. H. Rosado-Neto ${ }^{b}$ and E. G. F. Morais ${ }^{c}$ \\ ${ }^{a}$ Embrapa Trigo, Rodovia BR 285, Km 294, CP 451, CEP 99001-970, Passo Fundo, RS, Brazil \\ bUniversidade Federal do Paraná, CP 19020, CEP 81531-980, Curitiba, PR, Brazil

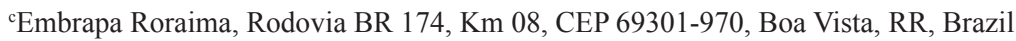 \\ *e-mail: alberto.marsaro@embrapa.br
}

Received: January 20, 2016 - Accepted: May 30, 2016 - Distributed: November 31, 2016

(With 6 figures)

\begin{abstract}
The weevil of acerola fruits, Anthonomus tomentosus (Faust, 1894) (Coleoptera: Curculionidae), is recorded for the first time in Brazil. Samples of this insect were collected in fruits of acerola, Malpighia emarginata D.C. (Malpighiaceae), in four municipalities in the north-central region of Roraima State, in the Brazilian Amazon. Information about injuries observed in fruits infested with $A$. tomentosus, its distribution in Roraima, and suggestions for pest management are presented.
\end{abstract}

Keywords: Brazilian Amazon, quarantine pests, fruticulture, geographical distribution, host plants.

\section{Primeiro registro do bicudo dos frutos da acerola, Anthonomus tomentosus (Faust, 1894) (Coleoptera: Curculionidae), no Brasil}

\section{Resumo}

O bicudo dos frutos da acerola, Anthonomus tomentosus (Faust, 1894) (Coleoptera: Curculionidae), é registrado pela primeira vez no Brasil. Amostras deste inseto foram coletadas em frutos de acerola, Malpighia emarginata D.C. (Malpighiaceae), em quatro municípios do Centro-Norte do Estado de Roraima, na Amazônia brasileira. Informações sobre as injúrias observadas nos frutos infestados por A. tomentosus, sua distribuição em Roraima e sugestões para o seu manejo são apresentadas.

Palavras-chave: Amazônia brasileira, pragas quarentenárias, fruticultura, distribuição geográfica, plantas hospedeiras.

\section{Introduction}

Malpighiaceae is a plant family of approximately 63 genera and 850 species, of which around 30 belong to the genus Malpighia (Joly, 1983; Nakasone and Paull, 1998 apud Oliveira et al., 2003). The distribution area of the acerola or Barbados cherry (Malpighia emarginata) is centered in the Tropical Americas, and the acerola tree reproduces by natural vegetative propagation in the Caribbean region, more specifically in southern Mexico, Central America, and northern South America, although its exact place of origin is unknown (Soares Filho and Oliveira, 2003).

In Brazil, there is evidence of acerola cultivation in small orchards in the city of Rio de Janeiro/RJ since the first half of the $19^{\text {th }}$ century and in the municipality of Limeira/SP in 1940, with later introduction into the northeastern region of the country, in the state of Pernambuco, in 1958 (Soares Filho and Oliveira, 2003). The acerola is currently found from northern to southern Brazil. The total area covered by acerola orchards in Brazil is estimated to exceed
10,000 ha, mainly in the states of Bahia, Ceará, Paraíba, and Pernambuco, and secondarily in Pará and São Paulo. Northeastern Brazil accounts for over $60 \%$ of the total yield of acerola fruits produced in the country, which is the top global producer - ahead of Puerto Rico and the USA (Hawaii and Florida), where this fruit crop is also traditionally grown (Soares Filho and Oliveira, 2003).

Acerola orchards in Brazil are infested by various types of pest insects. In the state of Bahia, the main pest species that cause injury to acerola fruits are Aphis spiraecola (Patch) (Hemiptera: Aphididae), Crinocerus sanctus (Fabricius) (Hemiptera: Coreidae), Orthezia praelonga Douglas (Hemiptera: Ortheziidae), Bolbonata tuberculata (Coqueberg) (Hemiptera: Membracidae), Coccus hesperidium Linnaeus (Hemiptera Coccidae), Ceratitis capitata (Wiedemann) and Anastrepha spp. (Diptera: Tephritidae), Atta spp. (Hymenoptera: Formicidae), and Anthonomus acerolae (Clark) (Coleoptera: Curculionidae) (Nascimento et al., 2003). 
Several species of Anthonomus have been associated with acerola crops worldwide. In Mexico, Anthonomus sisyphus Clark, A. unipustulatus Champion, A. caracasius (Faust), and A. alboscutellatus Champion are reported as important pests of acerola (Yee, 1999). The first two species attack the fruits, whereas the latter two attack the flower buds of Malpighia glabra. These species can cause significant losses to production and significantly compromise the aesthetic value of the fruits (Yee, 1999). In Florida, A. macromalus Gyllenhal $(=A$. flavus $)$ is also reported as an important pest of acerola (Ooi et al., 2002). According to Stegmaier and Burke (1974), who reviewed the biology of $A$. macromalus, females deposit their eggs on flower anthers and unripe fruits. Larvae develop on flowers and fruits, causing major injury to the floral reproductive structures and to the flesh of the fruits, resulting in a smaller yield.

An additional species associated with acerola, A. acerolae, was described from specimens collected in Brazil in the states of Bahia, Espírito Santo, Minas Gerais, and Rio Grande do Norte (Clark, 1988). According to Nascimento et al. (2003), females deposit their eggs in flower buds and feed on ripe fruit, whereas larvae feed on flower buds, destroying them; in both cases, productivity is compromised. According to the authors, the weevil has great destructive potential, and the levels of damage to the flower buds should be assessed.

Anthonomus tomentosus (Faust) has also been associated with plants of the genus Malpighia (M. emarginata, M. glabra, and Malpighia sp.) (Clark, 1987). Apart from these associations, no information is available on the bioecology of this weevil, such as its biology, damage caused to host plants, and natural enemies. The existing studies on the morphology of $A$. tomentosus have been conducted using specimens collected in Venezuela (El Limón, Montalbán, Maracaibo, Cariaco, La Esmeralda, Pantoño, and Caracas) and Trinidad (Curepe) (Clark, 1987). Therefore, to date, reports of this species have been restricted to those two countries.

This work aims to record the occurrence of $A$. tomentosus in Brazil, reveal its current distribution in the state of Roraima, characterize the injuries observed in fruits infested by the species, and provide suggestions for its management.

\section{Material and Methods}

In October 2010, ripe fruits of acerola (Malpighia emarginata) infested by Curculionidae larvae and pupae were collected in the state of Roraima, Brazil, in the municipalities of Boa Vista (N 02 ${ }^{\circ} 51^{\prime}$ 24.4" and W 60 39'37.1”), Mucajaí (N 02 ${ }^{\circ} 26^{\prime} 08.8^{\prime \prime}$ and W 60 55'08.2”), Pacaraima (N 04 ${ }^{\circ} 28^{\prime} 51.1^{\prime \prime}$ and W 61 ${ }^{\circ} 08^{\prime} 33.3^{\prime \prime}$ ) and, in November 2015, in Normandia (N $03^{\circ} 52^{\prime}$ 50.9" and W 59 $37^{\circ}$ '58.6”). The fruits were transported to the Entomology Laboratory at Embrapa Roraima, in the city of Boa Vista/RR, and stored in mesh-covered plastic jars containing a thin layer of vermiculite, until the adults emerged. The adults were subsequently preserved in Eppendorf tubes containing $70 \%$ ethanol and transported to the Entomology division of the Zoology Department at the Federal University of Paraná (UFPR), in the city of Curitiba/PR, Brazil, for taxonomic identification. In the laboratory, the adults were mounted on entomological pins and examined under a stereomicroscope with a 10x ocular lens and 50x objective lens, providing magnifications of up to 500x. The morphological characters of the studied species were interpreted according to Clark (1987), whose review of Anthonomus species in the unipustulatus group included descriptions and an identification key.

To confirm species identification, adult specimens mounted on entomological pins were sent to Dr. Wayne E. Clark at the Entomology and Plant Pathology Department at Auburn University, Alabama/USA. The mounted specimens were deposited in the Entomology Collection of the Zoology Department at the Federal University of Paraná (UFPR) in Curitiba/PR, Brazil, and in the Collection of the Entomology and Plant Pathology Department at Auburn University, Alabama/USA.

An additional experiment was conducted to assess the levels of weevil infestation in acerola fruits at different stages of ripeness. In Boa Vista/RR, in July 2010, 100 fruits were collected from one acerola tree (M. emarginata): 25 unripe fruits without signs of infestation (no deformities in the fruit), 25 unripe fruits with signs of infestation (with deformities), 25 partially ripe fruits with signs of infestation, and 25 ripe fruits with signs of infestation. The experimental design was completely casualized, each fruit being treated as one repetition. The fruits, which weighted $3.0 \mathrm{~g}$ on average, were individually stored in mesh-covered plastic jars containing a thin layer of vermiculite and kept in a climate-controlled room at $25^{\circ} \mathrm{C}$ and $75 \%$ R.H., until all adults had emerged. A variance analysis of the total number of adults/fruit was performed, using the $\sqrt{ }(x+1)$ transformation, and the mean values were compared by Tukey testing at $1 \%$ probability. Statistical analyses were conducted using the GENES computer program (Cruz, 2006).

\section{Results}

All specimens, both male and female, obtained from the acerola fruits collected in the municipalities of Boa Vista, Mucajaí, Pacaraima and Normandia were identified as Anthonomus tomentosus (Faust, 1894) (Coleoptera: Curculionidae), a species previously unreported in Brazil (Figure 1).

According to Clark (1987), adult males have a body length of 1.5 to $2.1 \mathrm{~mm}$, width between humeri of 0.7 to $1.2 \mathrm{~mm}$, and rostrum length of 1.0 to 1.2 times the length of the pronotum (Figure 2). Adult females have a body length of 1.5 to $2.2 \mathrm{~mm}$, width between humeri of 0.7 to $1.1 \mathrm{~mm}$, and rostrum length of 0.9 to 1.9 times the length of the pronotum (Figure 3). Males and females with scales on the pronotum and elytra ranging from cinereous to fulvoaeneus in color. 


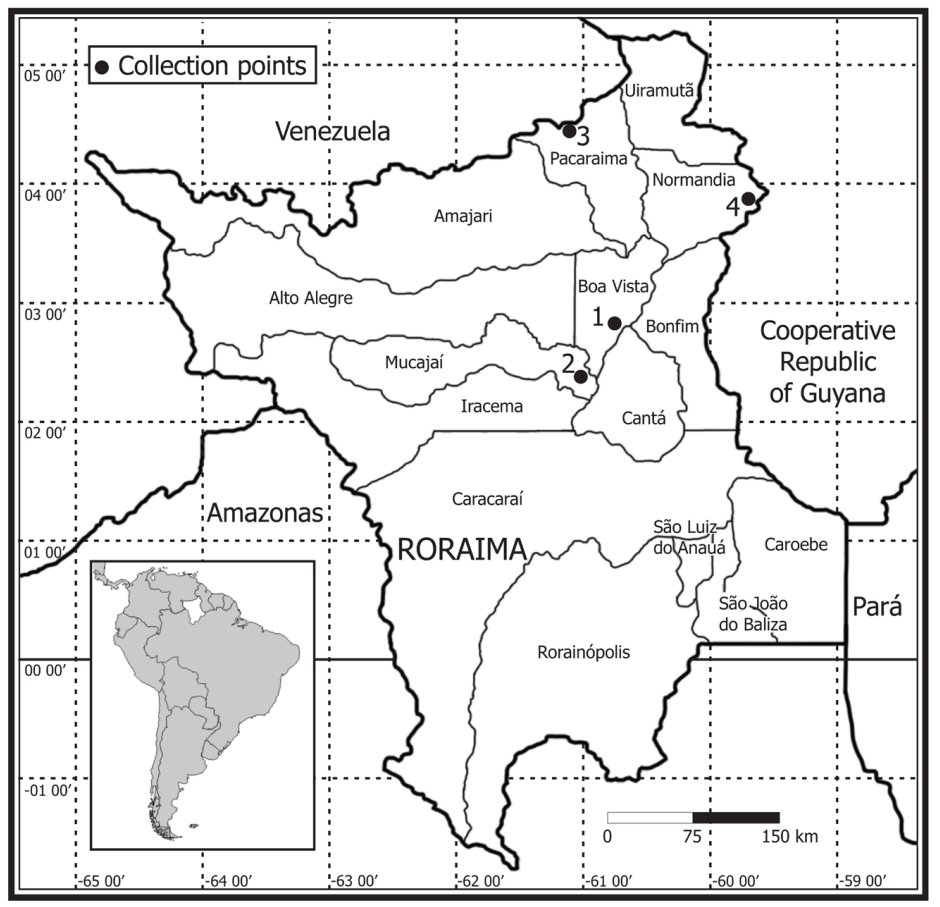

Figure 1. Map of the state of Roraima, indicating the locations in each municipality where Anthonomus tomentosus (Faust, 1894) was collected.

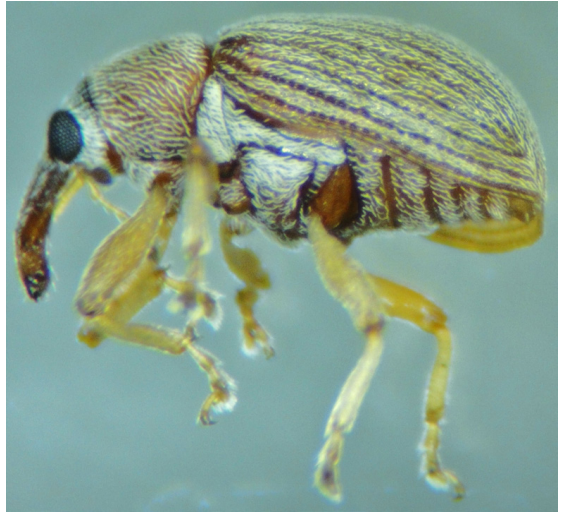

Figure 2. Adult male of A. tomentosus. Photo: Marsaro Júnior, A.L.

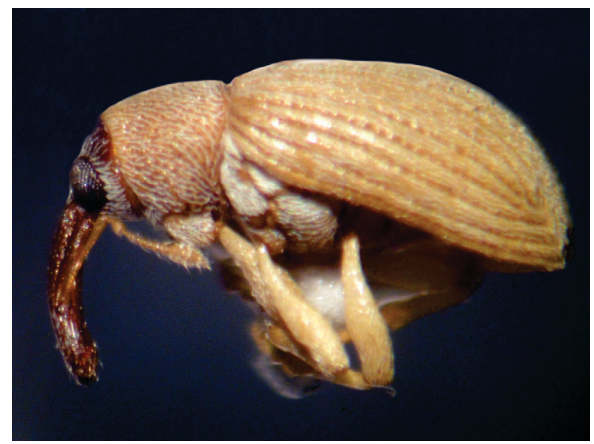

Figure 3. Adult female of A. tomentosus. Photo: Marsaro Júnior, A.L.
The injuries observed in the fruits are caused by larvae (Figure 4), which cause qualitative and quantitative losses as they feed on the flesh (mesocarp) (Figure 5). The infested fruits (unripe, partially ripe, and ripe) become deformed, compromising their aesthetic value as in natura products (Figure 6). In our fruit infestation assessment, we found that fewer adults emerged from undeformed, unripe fruits, on average, than from fruits at other stages of ripeness (Table 1).

\section{Discussion}

The fruit deformities observed in this study, resulting from infestation by larvae of $A$. tomentosus, are similar to the deformities caused by larvae of $A$. macromalus in fruits of acerola in Florida, USA (Stegmaier and Burke, 1974). These deformities compromise the aesthetic value of the fruits, and therefore also compromise the marketability of acerola grown for in natura consumption, bringing losses to growers. Organoleptic alterations to the flesh, such as altered odor and flavor, also occur and can be detrimental to the marketability of fruits grown for in natura consumption or for the fruit concentrate industry. Given that other species of Anthonomus are capable of significantly compromising the productivity of acerola orchards (Yee, 1999), studies are necessary to determine the impacts of infestation by A. tomentosus on acerola production in Brazil.

Little information is available on the biology of Anthonomus species that occur in acerola orchards. Stegmaier and Burke (1974) mentioned that the larvae of A. macromalus probably go through three instars. In the 


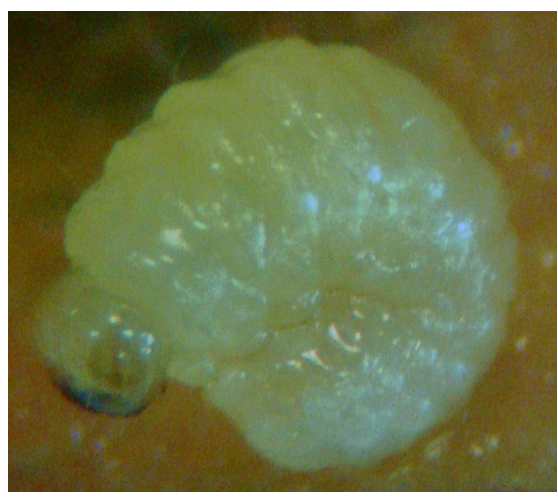

Figure 4. Larva of A. tomentosus. Photo: Marsaro Júnior, A.L.

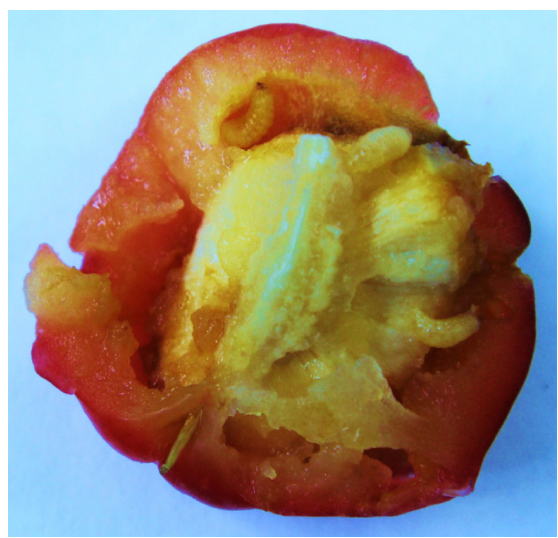

Figure 5. Injuries to mesocarp of acerola fruit infested by larvae of A. tomentosus. Photo: Marsaro Júnior, A.L.

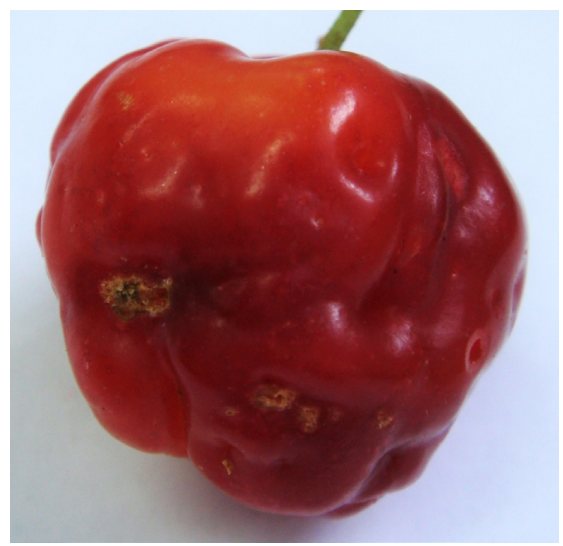

Figure 6. Injuries to epicarp of acerola fruit infested by larvae of A. tomentosus. Photo: Marsaro Júnior, A.L. present study, based on fruits stored in mesh-covered jars in the laboratory, we observed the emergence of up to nine adults of $A$. tomentosus from a single acerola fruit. This indicates that the species has a high biotic potential. Stegmaier and Burke (1974), in Florida, also observed a high biotic potential for $A$. macromalus in acerola fruits. The authors observed up to 20 larvae developing in a single fruit. Also in Florida, studying the same species, Hunsberger et al. (1998) observed infestations by up to 23 larvae in a single fruit of acerola, with up to 4.7 adults emerging per fruit, on average. In an assessment of infestation of Malpighia mexicana fruits in Mexico, Jarquín-López et al. (2011) reported up to 3.07 adults of $A$. sisyphus emerging per fruit, on average. These levels of infestation, though reported for other species of Anthonomus, are similar to those observed for A. tomentosus in this work (Table 1).

The emergence of adults from unripe fruits, observed in this study, indicates that females lay eggs when the fruits are still unripe, similarly to what Stegmaier and Burke (1974) observed for $A$. macromalus.

For management of $A$. macromalus in Florida, Hunsberger et al. (1998) reported that population peaks of the adults were observed in the summer, coinciding with the flowering and fruiting periods of their host plant. In light of this, Ooi et al. (2002) stated that the most appropriate time for insecticide spraying in order to control the adults seems to be in the spring, before the increase in population densities of these insects. On the other hand, the authors emphasize that given the irregular and overlapping fruiting pattern of acerola, the fruits may support multiple generations of the weevil, permitting rapid reinfestation of the orchard.

In Brazil, Nascimento et al. (2003) stated that the characteristics of the acerola life cycle - such as its short interval between flowering and fruit ripening (roughly 20 days) and multiple flowering periods throughout the year - mean that chemical pesticides should be applied under strictly controlled conditions in order to avoid the presence of pesticide residues on the fruits upon harvesting.

It should be noted that only one insecticide is currently registered for pest control in acerola orchards in Brazil. This chemical, a spinosyn, is targeted at Anastrepha spp. and $C$. capitata fruit flies (Brasil, 2015). Further studies are therefore necessary aiming to make a wider range of chemical and biological insecticides available in the future, with short safety intervals and low residue levels. This will enable acerola producers to efficiently manage the pests that afflict their orchards, while bringing fewer impacts to the environment and more safety for consumers.

Table 1. Mean \pm standard error of number of adults/fruit of $A$. tomentosus in acerola fruits at different stages of ripeness

\begin{tabular}{ccccc}
\hline $\begin{array}{c}\text { Stage of } \\
\text { ripeness }\end{array}$ & $\begin{array}{c}\text { Partially ripe fruit, } \\
\text { with deformities }\end{array}$ & $\begin{array}{c}\text { Unripe fruit, with } \\
\text { deformities }\end{array}$ & $\begin{array}{c}\text { Ripe fruit, with } \\
\text { deformities }\end{array}$ & $\begin{array}{c}\text { Unripe fruit, } \\
\text { without deformities }\end{array}$ \\
\hline $\begin{array}{c}\text { Mean number of } \\
\text { adults/fruit } \\
\text { CV } \%\end{array}$ & $3.60 \pm 0.57 \mathrm{a}$ & $3.20 \pm 0.55 \mathrm{a}$ & $2.80 \pm 0.59 \mathrm{a}$ & $0.52 \pm 0.21 \mathrm{~b}$ \\
\hline
\end{tabular}

Means followed by the same letter in the same row are not significantly different, under the Tukey test $(\mathrm{p}<0.01)$. 
With regard to the possibility of behavioral control of A. tomentosus, we would like to note that the aggregation pheromones of several species of Anthonomus are already known, as reviewed by Ambrogi et al. (2009). Some pheromonal compounds are common to these species. Aiming to increase the efficiency of trapping of A. macromalus adults by yellow sticky traps in the field, Hunsberger et al. (1998) added pheromones of Anthonomus grandis Boheman and Anthonomus eugenii Cano to these traps. However, using these pheromones did not increase trapping efficiency.

During field collections in the present study, we observed several couples of $A$. tomentosus copulating on acerola fruits. This indicates that $A$. tomentosus probably produces aggregation pheromones, as already reported by Ambrogi et al. (2009) for other species of Anthonomus. Therefore, future studies could investigate the occurrence of these pheromones and, if their existence is confirmed, the respective compounds could be identified, synthesized, and incorporated into traps, as part of efforts to monitor and control the adults of $A$. tomentosus.

As regards cultural control measures for A. tomentosus, we suggest that fallen fruits be removed and buried, given that these fruits are sources of adults for subsequent infestations, as reported by Hunsberger et al. (1998) for A. macromalus.

Natural biological control of Anthonomus spp. has also been conducted in acerola orchards, mainly using larval parasitoids. In Florida, the main species of parasitoid associated with A. macromalus is Catolaccus hunteri Crawford (Hymenoptera: Pteromalidae) (Hunsberger and Peña, 1997). In Mexico, associated with A. sisyphus, Jarquín-López et al. (2011) found seven species of parasitoids belonging to the families Braconidae, Pteromalidae, and Eupelmidae, the most abundant being the braconids Diospilus sp., Bracon sp., and Triaspis eugenii Wharton and Lopez-Martinez. The authors state that the highest rate of parasitism found was $16.97 \%$ and this percentage was possibly due to the location where the fruits were collected - an ethnobotanical garden with a wide diversity of plants, providing these parasitoids with shelter, food, and hosts.

No parasitoids were observed in the samples of fruits collected in Roraima, but our surveys were localized and the number of sampled fruits was small. Therefore, new samplings of fruit, at greater numbers and at various locations throughout the state, should be performed to prospect for natural enemies of $A$. tomentosus.

As for preventive measures to avoid dispersion of A. tomentosus to other municipalities in the state of Roraima and other states in Brazil, based on the behavior of this pest species, we suggest preventing the transport of fruits (unripe, partially ripe, or ripe) from infested locations into non-infested locations.

We believe that $A$. tomentosus first entered Brazil by crossing the border with Venezuela, where this species has been collected in many regions of the country, as reported by Clark (1987). This introduction may have occurred in one of two ways. The first is natural dispersion, given the geographic proximity and presence of host plants in both countries. The second possibility is that fruits infested by the pest in Venezuela were transported into Brazil. Given the ease of access by road between both countries, effectively unifying the area into a single territory, the Brazil-Venezuela border undergoes an intense circulation of people and of plant-based products. It is therefore possible that tourists have inadvertently carried acerola fruits infested by $A$. tomentosus from Venezuela into Brazil.

The distribution of $A$. tomentosus in Roraima shows that the pest is found in the central and northern municipalities of the state (Figure 1). Given the availability of host plants in all regions of the state, the weevil may have already dispersed into other municipalities. New surveys are therefore required to better elucidate the distribution of this species in the state, as well as to investigate its potential presence in states adjacent to Roraima - especially in Amazonas, as the two states are connected by road.

After the identification of $A$. tomentosus was confirmed in Roraima, the Ministry of Agriculture, Livestock and Food Supply of Brazil (MAPA) was immediately notified, as per MAPA Normative Instruction No. 52 (IN 52) (Brasil, 2007). Preventive measures to mitigate the dispersion of this pest in Brazil are already in place, as per MAPA Normative Instruction No. 19 (IN 19) (Brasil, 2014), which declared the municipalities of Boa Vista, Mucajaí, and Pacaraima as interdicted zones and prohibited the transport of fresh acerola fruits (Malpighia spp.) to areas outside this zone. In addition, the area delineated by all other municipalities in the state of Roraima and the municipalities of Presidente Figueiredo, Rio Preto da Eva, and Manaus, in the state of Amazonas, were declared as zones of suspected occurrence of $A$. tomentosus. Also under IN 19, inter-state transport of fresh acerola fruits (Malpighia spp.) produced in this zone of suspected occurrence is only allowed upon issuance of a Plant Transit Permit (PTV), substantiated by a Phytosanitary Certificate of Origin (CFO) or Consolidated Phytosanitary Certificate of Origin (CFOC) containing the following additional statement: "The load has been inspected and is free of Anthonomus tomentosus".

\section{Final Considerations}

The recent and frequent introductions of other pest species of quarantine importance into Brazil through the state of Roraima - such as the Hindustan citrus mite, Schizotetranichus hindustanicus (Hirst) (Prostigmata: Tetranychidae) (Navia and Marsaro Júnior, 2010), the red palm mite, Raoiella indica Hirst (Acari: Tenuipalpidae) (Navia et al., 2011), the pink hibiscus mealybug, Maconellicoccus hirsutus (Green) (Hemiptera: Pseudococcidae) (Marsaro Júnior et al., 2013), and the scale insect Lecanodiaspis dendrobii Douglas (Hemiptera: Lecanodiaspididae) (Marsaro Júnior et al., 2016) - show the vulnerability of the Brazilian borders with the Cooperative Republic of Guyana and with Venezuela, when it comes to intercepting and avoiding the entry of exotic pests. This reinforces the need for larger investments in phytosanitary defense in Brazil, especially in border regions. 


\section{Acknowledgements}

We thank Dr. Wayne E. Clark at Auburn University, Alabama/USA, for confirming our taxonomic identification of Anthonomus tomentosus.

\section{References}

AMBROGI, B.G., VIDAL, D.M., ZARBIN, P.H.G. and ROSADONETO, G.H., 2009. Feromônios de agregação em Curculionidae (Insecta: Coleoptera) e sua implicação taxonômica. Química Nova, vol. 32, no. 8, pp. 2151-2158. http://dx.doi.org/10.1590/ S0100-40422009000800029.

BRASIL. Ministério da Agricultura, Pecuária e Abastecimento - MAPA, 2007 [viewed 20 May 2013]. Instrução normativa $n^{o}$ 52, de 20 de novembro de 2007. Estabelece a lista de pragas quarentenárias ausentes (A1) e de pragas quarentenárias presentes (A2) para o Brasil e aprova os procedimentos para as suas atualizações. Diário Oficial da República Federativa do Brasil, Brasília, 21 nov. Seção 1. Available from: http://sistemasweb. agricultura.gov.br/sislegis/action/detalhaAto.do?method=detal harAtosArvore $\&$ tipo $=I N M \&$ numeroA to $=00000052 \&$ seqA to $=$ $000 \&$ valor $A n o=2007 \&$ orgao $=$ MAPA $\& \operatorname{codTipo}=\&$ desItem $=\&$ desItemFim=\#

BRASIL. Ministério da Agricultura, Pecuária e Abastecimento - MAPA, 2014 [viewed 22 April 2015]. Instrução normativa $n^{\circ} 19$, de 16 de setembro de 2014. Diário Oficial da República Federativa do Brasil, Brasília, 23 set. Seção 1. Available from http://pesquisa.in.gov.br/imprensa/jsp/visualiza/index.jsp?jorna $1=1$ \&pagina $=3 \&$ data $=23 / 09 / 2014$

BRASIL. Ministério da Agricultura, Pecuária e Abastecimento - MAPA, 2015 [viewed 21 April 2015]. AGROFIT: sistema de agrotóxicos fitossanitários. Brasília. Available from: http://agrofit. agricultura.gov.br/agrofit_cons/principal_agrofit_cons

CLARK, W.E., 1987. Revision of the unipustulatus group of the weevil genus Anthonomus Germar (Coleoptera: Curculionidae). The Coleopterists Bulletin, vol. 41, no. 1, pp. 73-88.

CLARK, W.E., 1988. Review of the Anthonomus alboscutellatus species group, with descripition of a new species (Coleoptera: Curculionidae). The Coleopterists Bulletin, vol. 42, no. 4, pp. 379-386.

CRUZ, C.D., 2006. Programa Genes: estatística experimental e matrizes. Viçosa: UFV. 285 p.

HUNSBERGER, A.G.B. and PEÑA, J.E., 1997. Catolaccus hunteri (Hymenoptera: Pteromalidae), a parasite of Anthonomus macromalus (Coleoptera: Curculionidae) in South Florida. The Florida Entomologist, vol. 80, no. 2, pp. 301-304. http://dx.doi. org/10.2307/3495565.

HUNSBERGER, A.G.B., PEÑA, J.E., GIBLIN-DAVIS, R.M., GRIES, G. and GRIES, R., 1998. Biodynamics of Anthonomus macromalus (Coleoptera: Curculionidae), a weevil pest of Barbados cherry in Florida. Proceedings of the Florida State Horticultural Society, no. 111, pp. 334-338.

JARQUÍN-LÓPEZ, R., MARTÍNEZ-MARTÍNEZ, L., SÁNCHEZGARCÍA, J.A. and FIGUEROA, J.I., 2011. Parasitoides asociados a Anthonomus sisyphus Clark (Coleoptera: Curculionidae) en frutos de nanche rojo (Malpighia mexicana) en Oaxaca, México. Southwestern Entomologist, vol. 36, no. 3, pp. 351-361. http:// dx.doi.org/10.3958/059.036.0312.

MARSARO JÚNIOR, A.L., PERONTI, A.L.B.G., COSTA, V.A., MORAIS, E.G.F. and PEREIRA, P.R.V.S., 2016. First report of Lecanodiaspis dendrobii Douglas, 1892 (Hemiptera: Lecanodiaspididae) and the associated parasitoid Cephaleta sp. (Hymenoptera: Pteromalidae) in Brazil. Brazilian Journal of Biology $=$ Revista Brasileira de Biologia, vol. 76, no. 1, pp. 250255. PMid:26871743. http://dx.doi.org/10.1590/1519-6984.20314.

MARSARO JÚNIOR, A.L., PERONTI, A.L.B.G., PENTEADODIAS, A.M., MORAIS, E.G.F. and PEREIRA, P.R.V.S., 2013. First report of Maconellicoccus hirsutus (Green, 1908) (Hemiptera: Coccoidea: Pseudococcidae) and the associated parasitoid Anagyrus kamali Moursi, 1948 (Hymenoptera: Encyrtidae), in Brazil. Brazilian Journal of Biology $=$ Revista Brasileira de Biologia, vol. 73, no. 2, pp. 413-418. PMid:23917571. http:// dx.doi.org/10.1590/S1519-69842013000200024.

NASCIMENTO, A.S., SÁ, W.M.S., SOGLIA, M.C.M. and OLIVEIRA, J.R.P., 2003. Insetos-praga e seu controle. In: R. RITZINGER, A.K. KOBAYASHI, J.R.P. OLIVEIRA, eds. $A$ cultura da aceroleira. Cruz das Almas: Embrapa Mandioca e Fruticultura, pp. 119-132.

NAVIA, D. and MARSARO JÚNIOR, A.L., 2010. First report of the Citrus Hindu Mite, Schizotetranychus hindustanicus (Hirst) (Prostigmata: Tetranychidae), in Brazil. Neotropical Entomology, vol. 39, no. 1, pp. 140-143. PMid:20305912. http://dx.doi. org/10.1590/S1519-566X2010000100021.

NAVIA, D., MARSARO JÚNIOR, A.L., SILVA, F.R., GONDIM JÚNIOR, M.G.C. and MORAES, G.J., 2011. First report of the Red Palm Mite, Raoiella indica Hirst (Acari: Tenuipalpidae), in Brazil. Neotropical Entomology, vol. 40, no. 3, pp. 409-411. PMid:21710040. http://dx.doi.org/10.1590/S1519-566X2011000300018.

OLIVEIRA, J.R.P., SOARES FILHO, W.S., KOBAYASHI, A.K. and RITZINGER, R., 2003. Aspectos botânicos. In: R. RITZINGER, A.K. KOBAYASHI, J.R.P. OLIVEIRA, eds. $A$ cultura da aceroleira. Cruz das Almas: Embrapa Mandioca e Fruticultura, pp. 17-23.

OOI, P.A.C., WINOTAI, A. and PEÑA, J.E., 2002. Pests of minor tropical fruits. In: J.E. PEÑA, J.L. SHARP, M. WYSOKI, eds. Tropical fruits pests and pollinators: biology, economic importance, natural enemies and control. Wallingford: CABI Publishing, pp. 315-330.

SOARES FILHO, W.S. and OLIVEIRA, J.R.P., 2003. Introdução. In: R. RITZINGER, A.K. KOBAYASHI, J.R.P. OLIVEIRA, eds. A cultura da aceroleira. Cruz das Almas: Embrapa Mandioca e Fruticultura, pp. 15-16.

STEGMAIER, C.E. and BURKE, H.R., 1974. Anthonomus flavus (Coleoptera: Curculionidae) a fruit-infesting weevil of the Barbados cherry, Malpighia glabra (Malpighiaceae), new to North America. The Florida Entomologist, vol. 57, no. 1, pp. 81-90. http://dx.doi.org/10.2307/3493837.

YEE, W.L., 1999. Temporal distributions of Conotrachelus and Anthonomus weevils (Coleoptera: Curculionidae) and Malpighia glabra fruit yields in el Trapiche, Mexico. Southwestern Entomologist, vol. 24 , no. 3 , pp. $233-242$. 